\title{
Sanat Stil İlişkisi Üzerine Motosiklet Tasarımı Üzerinde Bir Araştırma
}

\author{
Applied Style, Art and Design in Relation to Motorcycle Designs
}

\begin{abstract}
Altuğ AKARPA * Harun DILER **

Öz: Bu çalışma sanat akımları ile ürün tasarımı sürecinin bir arada uygulanmasını ele almaktadır. Araştırma ve uygulama için günümüzde aktif olarak kullanılan motosiklet ürününe odaklanmaktadır. Motosiklet tasarımlarını sanatsal açıdan ele alarak -tasarım ilkeleri (ritim, denge, oran-orantı/ölçek, vurgu, zıtlık, bütünlük, hiyerarşi) gibi sanat akımlarının sahip oldukları özgün estetik değerleri ile inceleyip uygulamayı amaçlamaktadır. Bu yolla motosiklet tasarımı üzerinde görsel denemeler yapılarak sanat ve tasarım ilişskisinin uygulama boyutunda araştırılması amaçlanmaktadır. Bunlarla birlikte yapılan teorik ve pratik çalışmalar ile tasarım süreci ve tasarım yöntemleri üzerine eklenebilecek katkıların saptanması açısından araştırma önem arz etmektedir. Bu çalışmanın araştırma ve uygulama sürecinde tercih edilen yöntem nicel araştırma yöntemidir. Nicel araştırma yöntemlerinden olan betimsel tarama yöntemi ile verilerin test edilmesi ve buna bağlı olarak incelenmesi yapılan araştırmalar ve alan uzmanlarının yönlendirmesi sonucunda kararlaştırılmıştır. Araştırmaya en uygun veri toplama metodunun anket olduğu belirlenmiştir. Alan uzmanlarına danışılarak alınan öneriler ve yönlendirmeler bağlamında anket soruları ve anketin genel tasarımı oluşturulmuştur. Araştırmanın anketi, veri toplama yollarının uygunluğu açısından alan uzmanına danışılıp, onay alındıktan sonra uygulanmıştır.
\end{abstract}

Anahtar sözcükler: Sanat, Tasarım, Stil, Motosiklet, Endüstriyel Tasarım

Abstract: This study examines the design principles through artistic perception. In order to investigate and apply this, the motorcycle products used today are focused upon. Through examining motorcycle designs from an art perspective, namely the design principles (rhythm, balance, rate ratio/scale, emphasis, contrast, integrity, hierarchy) and the analysis of typical aesthetic values within different art movements. In this way, by making experiments on motorcycle design, this paper investigates the relationship between art and design. Furthermore the aim has been to define design principles through art \& style perception in the shaping process, to determine what kind of contribution it can make to the design process and design methods through practical and theoretical studies. The method preferred in the research and application process of this study was the quantitative research method. It was decided as a result of the research conducted by the descriptive scanning method, one of the quantitative research methods, and according to the research and guidance of the field experts and it was determined that the most appropriate data collection tool was the questionnaire. In the context of the suggestions and directions received in consultation with the field experts, the survey questions and the overall design of the survey were created. The questionnaire for this research was applied after consulting the field expert and obtaining approval for the suitability of the manner of data collection.

Keywords: Art, Design, Style, Motorcycle, Industrial Design

* MA., Akdeniz Üniversitesi, Güzel Sanatlar Enstitüsü, altugakarpa@gmail.com

** Dr. Öğr. Ü., Akdeniz Üniversitesi, Teknik Bilimler Meslek Yüksekokulu, Antalya. hdiler@akdeniz.edu.tr https://orcid.org/0000-0002-9991-9847 
Moda ile plastik sanatlar, kavramsal sanat ve enstalasyonlar, mimari ve daha birçok alan disiplinler arası ürünler üretmiştir. Resim, yıllar boyu grafik tasarıma, moda tasarımına ve görsel sanatlara temel oluşturmuş, mimari ise form anlamında heykelden direkt olarak beslenmiştir.

Birçok tasarım alanında stiller aktif ve etkin olarak kullanılmışlardır. Buradaki kapsam, tespitler üzerine endüstriyel tasarım alanının incelediği bir ürün olan motosiklet ürününü sanat ve tasarım bağlamında irdelemektir. Bu yaklaşım sadece motosiklet için değil genel olarak ürün tasarımı üzerine stil anlamında plastik ve kavramsal bir tarz arayışı olarak da adlandırılabilir.

Kültürel ve sanatsal açıdan estetik değerlere vurgu yapılmasında belirgin bir artış vardır. Doğal olarak, estetik değerlerin öneminin artmasıyla, ürünlerin estetik özelliklerine odaklanılmış durumdadır. Günümüzde birçok bireysel veya kurumsal tasarımcı kendilerine ait ya da ait olmayan yerel estetik değerlere önem vermekte ve bunlar ile tasarımlar ortaya koymaktadır. Bauhaus'un klasik tasarım algısının kırılmasının yanı sıra insanın varoluşunun bitmez tükenmez arayışının bir sonucu olarak, sahip olduğu kavramsal ya da biçimsel araçları mümkün olduğunca kullanmanın alternatiflerini aramaktadır ve arayacaktır.

Çalışmanın öncelikli önemlerinden biri daha önce sanat akımlarının öğeleri belirlenerek motosiklet ölçeğinde bir tasarım ürününde kapsamlı olarak araştırılmamış olmasıdır. Bunun yanı sıra sanat ve tasarım ilişkisi üzerine araştırmalar olsa da, akademik olarak bu bağlamda tasarlanıp incelenen bir ürüne rastlanmamıştır.

Çalışmanın kapsamı; ritim, denge, oran-orantı (ölçek), vurgu, zıtlık, bütünlük, hiyerarşi gibi tasarım ilkelerini ve sanat akımlarının özel biçimlerini motosiklet tasarımında uygulamaktır. Konu kapsamında belirlenen "CBF 500" model motosikletin öğeleri olan egzoz, benzin deposu, jant gibi birçok parçası üzerinde belirlenen stiller bağlamında uygulamalar yapılacaktır. Siyah, sarı, kırmızı, mavi ve beyaz olmak üzere beş farklı renk, üç farklı sanat akımı özellikleri motosiklete uygulanacaktır. Seçilen sanat akımları; Barok, Konstrüktivizm ve Pop arttır.

\section{Sanat Akımları Stil ve Tasarım}

\section{Barok}

Barok sanata, psikolojik, duygusal ya da tinsel anlamda hareket egemendir. Rönesans'1n simetri ve oranı kıvr1lan formlar, koyu renkler ve çoğu kez karanlık ve aydınlık arasındaki dramatik zıtlığın yanında daha az belirgindir. Yanılsama yolu ile inandırma, dönüştürme, aldatma bütün bunlar Barok'un ișaretleridir. Resim bütün yönlere doğru ilerliyormuş, izleyici ile arasındaki psikolojik arayı kapatmak istiyormuş gibi görünür. Barok sanatlar izleyiciyi dönüştürmek, ikna etmek için ifadenin gücünü kullanmışlardır. Barok sanat hareketi yalnızca dışa değil içe de dönüktür. Yüksek drama ve güçlü duygu barok sanatın öyküsünde egemen aktörlerse de daha sessiz içedönük türlerinin taşıdığı mahremiyet, kurnazlık, düşüncelilik dışa dönük yanlar kadar esastır (Little 2006, 42).

Barok sanatta görsel olarak da kıvrımlı, gösterişli hatlar egemendir. Dönemin mobilya ve mimari eserlerinde de öne çıan motifler resim ve diğer

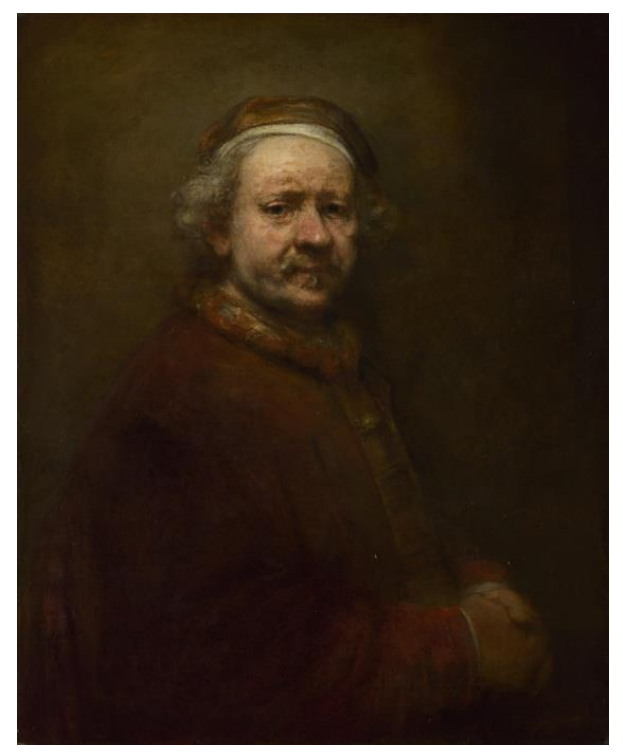

Fig. 1. Rembrandt, Otoportre, 1669

Kaynak:www.nationalgallery.org.ukpain tingsrembrandt-self-portrait-at-the-ageof- 63 
alanlardakilere benzerlik gösterir. Kıvrımlı ve katmanlı oymalar, kanat, aslan ayakları, kıvrımlı dallar ve kadın yüzleri gibi motifler oldukça belirgindir. Formun bütününden çok detayların ayrı ayrı birer değer olmalarına özen gösterilir.

\section{Konstrüktivizm (Yapısalcılık)}

Uluslararası bir akım olan konstrüktivizm, sanatın sınırları içinde kalan bir gelişmeydi. Konstrüktivizm, genellikle basit geometrik biçimler ve endüstriyel malzemeden yararlanan heykelciliğin bir kolu sayılır (Lynton $2015,110)$.

Vladimir Tatlin'in Sovyet devrimine ve komünizme olan sonsuz inancın simgesi olarak tasarladığ 3 . Enternasyonal Anıtı (Bk.. Fig. 8), resim, heykel ve mimarinin benzersiz bileşiminin ütopik bir ifadesidir (Antmen 2016, 102). Yapımcı sanatçılar bir heykel yada resim oluşturmak yerine, mekan içinde bir yapım (konstrüksiyon) oluşturmayı amaçlarlar. Resimler de daha çok geometrik biçimler arasındaki ilişkiyi araştıran yapımcılık, heykelde kitle ile boşluk arasındaki oranlarla estetik bir etkiye ulaşmayı ister. Mimarlıkta ise, bu

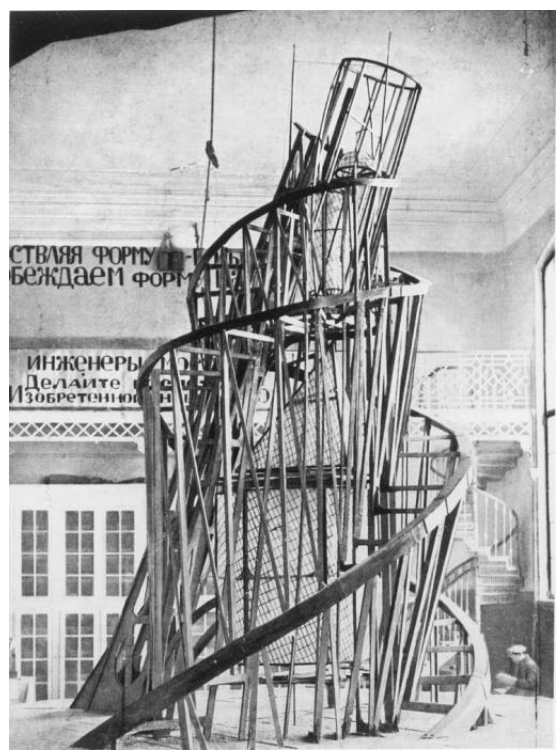

Fig. 2. Vladimir Tatlin, 3. Enternasyonal Anıtı ahşap maket, 1919-1921

Kaynak:www.moma.org.interactivesex hibitions2012/inventingabstractionwork $=226$ alanda üç bileşen olan biçim, işlev ve yapım arasından yapımın vurgulandığı bir görünüm alır. Yapılarda yapımın açıkça gösterilerek ön plana çıkarıldığı, hatta salt yapımdan oluşan yapıların önerildiği tasarımlar bulunmaktadır.

Rus Konstrüktivistleri, devrim ideolojisinin yaygınlık kazanması yolunda temel bir gereklilik olarak görülen çeşitli propaganda biçimleri kullanmışlardır. Bunların başında afişler, dergiler ve resimler gelir (Antmen 2016, 106).

Yapımcı sanatçılar eğik, çapraz düzenleme ve yerleştirmeler kullanarak yapitlarında gerilimi yüksek bir hareketlilik etkisi elde etmişlerdir. Yapımcilık, heykelde geleneksel malzeme ve biçimlendirme yöntemleri yerine çeșitli madenler, cam, plastik ve naylon gibi teknoloji çağının ürünü malzemelerle kimi endüstriyel üretim yöntemini kullanmasiyla da yenilik getirmiştir.

\section{Pop Art}

Pop sanat, II. Dünya Savaşı sonrasında gelişen

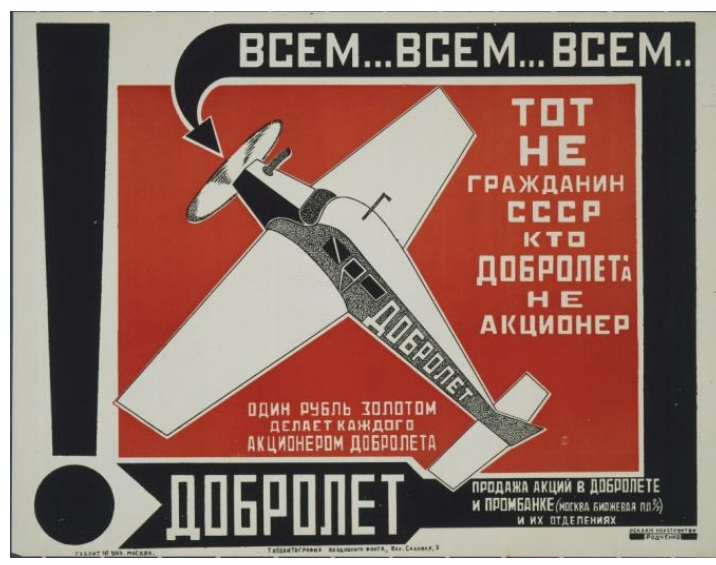

Fig. 3. Aleksandr Rodchenko, Dobrolet (Rus devlet havayolları için poster), 1923. Kaynak: batgre.wordpress.comtypographic-studiespioneersof-graphic-designresearch-typographers

ekonominin etkisiyle varlığını hissettirmeye başlayan tüketim kültürü ve zihniyetini gözler önüne serer ve bu anlamda son derece "Amerikalı" bir içeriğe sahiptir. Pop art, uluslararası sanat ortamında Amerikan varlığını ilk kez güçlü bir biçimde hissettiren Amerikan Soyut Dışavurumculuk akımının egemen konumuyla yarışmak zorunda kalmıştır (Antmen 2016, 161). Amerika'da geniş toplulukların gözünde tüketimi çekici bir konuma getirmek için renkli afişler, resimli dergi ve romanlar, medya ve sinema Pop art sanatçılarına esin kaynağı olmuştur. 
Amerikan pop sanatının etkinlik alanı, İngiltere'ye oranla daha genişti. Kitle iletişim araçlarındaki (televizyon, radyo, gazeteler ve dergiler) imgelerin uyandırdığı çekiciliği, en belirgin yoldan yapıtlarında kullanan sanatçılar, Roy Lichenstein ve Andy Warhol'dur (Lynton, 2015: 293). Bu sanatçılar yaşamı değil, tüketim dünyasının abartılı sunumunu eserleri ile ortaya koymuşlardır. Pop art, konserveden çorba ambalajına kadar hayli geniş bir yelpazede her türlü tüketim maddesini kendine konu olarak almıştır (Bk. Fig. 11).

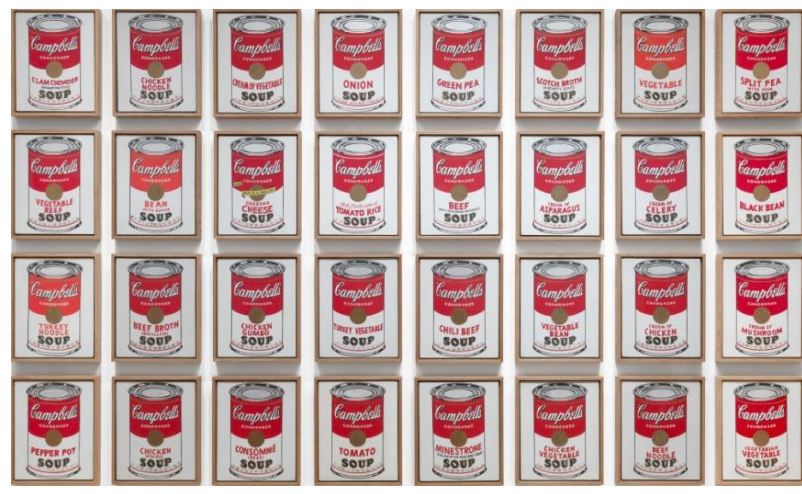

Fig. 4. Andy Warhol, Campbells'ın Çorba Konserveleri, 1962. Kaynak:

www.moma.orglearnmoma_learningandy-warholcampbells-soup-cans-1962

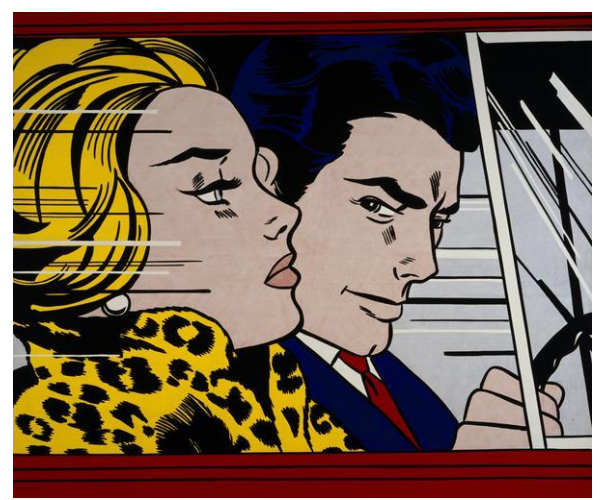

Fig. 5. Roy Lichenstein, Arabada, 1963.

Kaynak: www.nationalgalleries.orgart-andartists664car

Pop sanatçıları, elit bir kesimin beğenisine yönelik 'yüksek kültür' ile daha geniş kitlelere yönelik kültür tüketme biçimleri arasındaki ayrımları yok ederken öncelikle hazır-imgelerden yararlanmışlar, izleyicinin gündelik yaşamının bir parçası olan nesneleri iki-boyutlu yüzeylere aktarmışlardır. Reklamlar, afişler, çizgi romanlar ve filmlerle, özellikle de Hollywood endüstrisiyle yakından ilgilenen pop sanatçıları için bir dönemin popüler film yıldızları da vazgeçilmez bir esin kaynağı olmuştur. Kadın imgesi pop sanatın başlıca konularından birisi olarak cinsellikle yüklenmiş, seyirlik bir nesne konumundadır (Antmen 2016, 162).

\section{Stil}

Stil sözcüğü, eski İngiliz dilinde edebi bir anlatım anlamında kullanılmıştır ve sözcüğün kökeni Latince kalem anlamına gelen "stylus" sözcüğüdür. Türk Dil Kurumu stili (üslup), "Bir sanatçıya, bir çağa veya bir ülkeye özgü teknik, renk, biçimlendirme ve söyleyiş özelliği, biçem" olarak tanımlanırken, Cambridge Sözlüğü’nde stil, "Bir şeyi, bir insana, bir gruba, bir yere veya bir döneme özgü yapmanın tipik yolu" olarak tanımlanmaktadır. Tüm bu tanımlarda, stil, ifade şekli ne olursa olsun ifadenin ayırt edici özelliğini ifade eder.

Stilin kelime karşıllğı olarak üslup ve tarz kelimeleri kullanılabilir ancak bunlar stili tam olarak anlatmazlar. Kısaca tanımlayacak olursak stil; bir ürünün, bir resmin, bir yazının, dönemin, biri tarafından yapılmış olan her şeyin, özelliklerini ve özgünlüğünü biçimsel, anlamsal ya da başka yönlerden farklılığını veya aynılığını bize aktaran ifade biçimidir.

Farklı akademik alanlarının stil konseptine yaklaşımı, bu kavramın çok fazla irdelenmediği endüstriyel tasarım alanı ve diğer tüm alanlar için de geçerli ve önemlidir. Genel anlamda ve endüstriyel tasarımda stil bir şeyin belirlenmesi, sınıflandırılması ve karakterize edilmesi için kullanılan bir anlama aracıdır. Standartlardan ve normlardan sıyrılmıştır ve ayırt edilebilirdir. Bir kombinasyon, bir strüktürdür, birçok elementin sentezidir; ve bu elementleri bir araya getirmenin alternatif yollarından yapılan seçimleri kapsamaktadır. Neyin söylenmek istediği ve nasıl söylendiği, stilin parçasıdır. 


\section{Tasarım}

Tasarım, insanı insan yapan temel, ayırt edici niteliklerden biridir; insan yaşamının kalitesini belirleyen olmazsa olmazlardandır (Heskett 2013, 11). Günlük yaşantımızın her alanında tasarımı görmek mümkündür. Tasarıma form (biçim) ve stil (biçem) yaratma pratiği olarak bakılabilir; fakat teorik olarak irdelediğimizde, tasarım kavramı, kelime kökeni dolay1sıyla da, birçok anlam basamağına sahiptir.

Oxford Sözlüğü'nde, "tasarım" kelimesi ilk kez 1588 'de yer almıştır. Tasarım, "Bir insan tarafından gerçekleştirilmesi gereken bir şey için tasarlanan bir plan veya şema, bir sanat eserinin ilk grafik taslağ veya uygulamalı sanatların bir işin yürütülmesi için bağlayıcı olacağı bir amaç (Oxford dictionaries web sözlüğü "design")". Türk Dil Kurumu ise tasarımı "Bir sanat eserinin yapının veya teknik ürünün ilk taslağı" olarak açıklamaktadır (tdk.gov.tr, 2019, "tasarım”). Mimarlık Sözlüğü’nde tasarım, "Alışılagelmiş günlük nesnelerden, mobilyadan, mimarlık ve peyzajdan kentsel planlamaya kadar uzanan ve insan yaratıcılı̆̆ına dayalı olarak çevreye estetik değer bir uyum getirmeyi amaçlayan üretim etkinliği; tasarımlama işi, dizayn" olarak tanımlanır (Hasol 2010, 450).

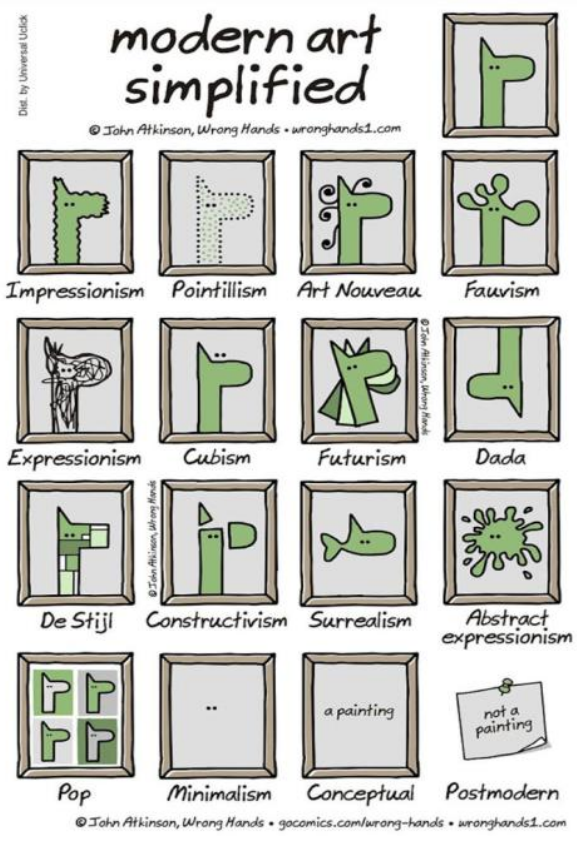

Fig. 6. John Atkinson, Resim alanında farklı stillerin kullanımı ile ilgili bir karikatür.Kaynak: modern-art-simplifiedcomic-guide-john-atkinson-wrong-hands-1

Tasarımlar insanların kararları ve seçimleri sonucunda oluşmuştur. Seçim yapmak beraberinde sorumluluğu getirir. Tasarım önemlidir, çünkü -dil ile birlikte- insan olmanın ayırıcı özelliklerinden birini tanımlar. Dünya üzerinde hiçbir varlık aynı türden bir yeteneğe sahip değildir. Kısacası, tasarlama yeteneği bir tür olarak insanın, varoluşumuzun tam da özünde bulunup sayısız yoldan kendini göstermektedir (Heskett 2013, 16).

\section{Tasarlanmiş Motosikletler Ve İçerikleri}

\section{Barok}

$\mathrm{Bu}$ motosiklet barok sanat akımının özellikleri doğrultusunda tasarlanmıştır. Motorda görülen rölyefler için barok döneme ait oturma elamanları, sehpalar, at arabaları, demir kapılar gibi çeşitli ürünler referans alınmıştır. Ve bu ürünlerdeki görsel unsurlar sanat akımının uygun gördüğü şekilde motosiklete uygulanmıştır.

Tasarımda kullanılan ve genel hatların oluşturulmasında da yararlanılmış görseller Barok sanatın "akışkan" ve "şatafatı" olma durumdan yola çıkarak tasarlanmıştır. Çamurlukların ve gövdenin birbirleriyle kurdukları görsel ilişki, barok sanatın birçok eserinde görülebileceği gibi döngüler, girintiler ve kabartmalarla yön ve biçim anlamında bağıntılı olarak tasarlanmıştır.

$\mathrm{Bu}$ tasarımda da teknik açılar ve ölçüler değiştirilmemiştir. Ancak motorda bulunan tüm grenaj ve benzer işlevdeki eklentiler (ön ve arka çamurluk, oturak altı davlumbaz vb.) çıkarılıp yerine Barok sanat akımının çizgilerine uygun bir komple kabuk (grenaj) oturtulmuştur. Bu kabuk üzerine de çeşitli barok döneme ait süslemeler uygulanmıştır.

Motosikletin jantları barok ve rokoko dönemlerindeki at arabaları tekerlekleri örnek alınarak geliştirilmiş ve düzenlenmiştir. 


\section{Konstrüktivizm (Yapısalcılık)}

$\mathrm{Bu}$ motosiklet konstrüktivizm (yapısalcılık) sanat akımı ile tekrar ele alınarak tasarlanmıştır. Bu tasarımda yapısalcılık sanat akımına dahil olan heykeller ve konsept tasarımlar incelenmiş ve bu eserlerden yola çıkılarak görsel ve kavramsal hatlar belirlenmiştir. İncelemeler sonunda karar kılınan ana unsur "boşluk" olmuştur. Yapısalcılık akımında heykel kitle ile boşluk arasındaki oranlarla estetik bir etkiye ulaşmayı ister. Belirlediğimiz bu bağlam gereği motosikletin üstündeki "fazlalık" her parça çıkartılmıştır. İşlevsel olanlar da mümkün olan en minimal hale getirilmiştir.

Örnek olarak benzin deposu hep alışılageldiği gibi motorun orta gövdesini kaplar halden çıkarılmış ve iç hacim olarak 1:3 oranında küçültülüp orta şasenin altına yerleştirilmiştir. Bu değişiklikle motorun ana gövdesinin ortaya çıkarılması ve görsel olarak motorun içindeki her şeyi daha fazla görebildiğimiz bir hal alması amaçlanmıştır. Aynı şekilde motorun orijinal versiyonunda bulunan yan grenajlar ile kapatılan gövde açllıp motor ve ekipmanları olabildiğince ortaya çıkarılmıştır.

Yapısalcılık akımı bağlamında görünen bazı parçalar yeniden ele alınarak baştan tasarlanmış veya hâlihazırda var olan bazı parçalara ekler yapılmıştır. Örneğin motorun yanındaki öne doğru uzanan şase parçası, işlev gözetmeksizin sadece akımın gerekleri doğrultusunda ana şaseye dahil edilmiştir. Şasenin arkaya doğru devam eden kısmina selenin yanı sira, stop lambası ve arka çamurluk da yerleştirilmiştir.

Şase, depo, sele, aydınlatma ve alt motor parçalarının uzantıları açısından motosiklet tamamen baştan ele alınmış ve yeni bir kimlik kazandırılmıştır.

\section{Pop Art}

Bu tasarım Pop art akımının özelliklerini taşıyacak şekilde ele alınmıştır. Pop art akımı ile ilgili yapılan araştırmalarda Pop artın en belirgin görsel ve kavramsal özelliklerinden ikisi seçilmiş ve motosikletin tasarımı genel fikri bu şekilde oluşmuştur. Kavramsal olarak Pop artın eleştirdiği ve sanat nesnesi olarak kullandığı "tüketim nesnesi" fikrini belirlemiş ve görsel olarak da renk ve grafiksel tasarımlarla bu fikir desteklenmiştir.

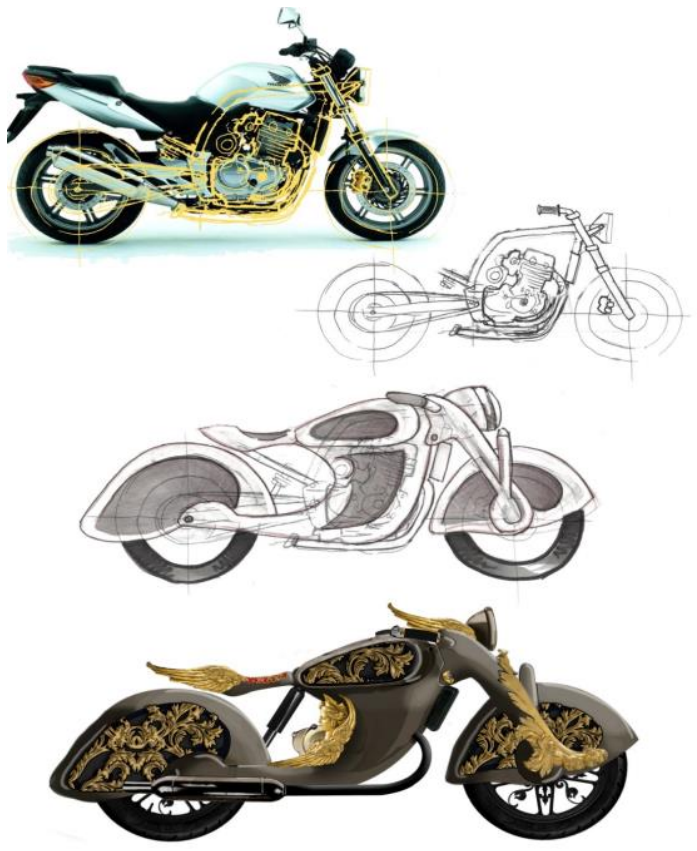

Fig. 7. Barok Stili

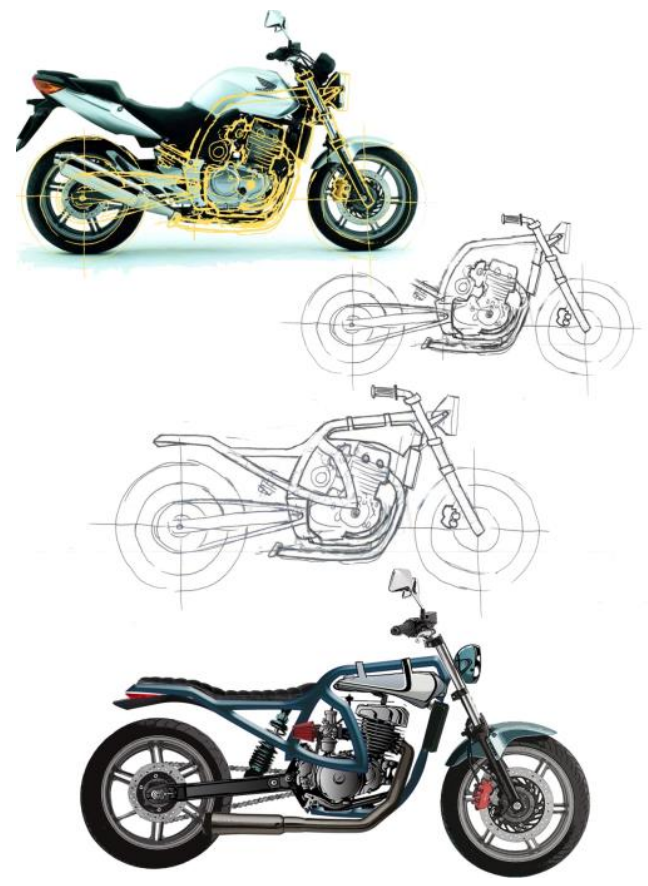

Fig. 8. Konsrüktivizm (Yapısalcılık) 
Motosikletin üst gövdesindeki, grenajlarındaki ve ön çamurluğundaki grafiksel giydirmeler form ve renk bakımından Pop arta öykünmektedir. Pop art'nn görsel anlamda en belirgin değeri renk ve sanat eserlerindeki grafiksel üsluptur. Bu tasarımda kullanılan grafiksel giydirmede kullanılan eserler grafik tasarımcı Butcher Billy'ye aittir.

Motosikletin formu modern tasarım normlarına uygun ve toplumsal arz talebe hitap edecek şekilde tasarlanmıştır. "Modern" görünen bu motor aslında "tüketim nesnesi" olması ve kendini pazarlaması için düşünülmüştür.

$\mathrm{Bu}$ tasarımda Pop art akımının "göz önünde olma" unsuru ele alınmış ve görsel düzenleme bu bağlamda şekillendirilmiştir.

\section{Metodoloji}

$\mathrm{Bu}$ çalışmanın araştırma ve uygulama sürecinde tercih edilen yöntem nicel araştırma yöntemidir. Nicel araştırma yöntemlerinden olan betimsel tarama yöntemi ile verilerin test edilmesi ve buna bağlı

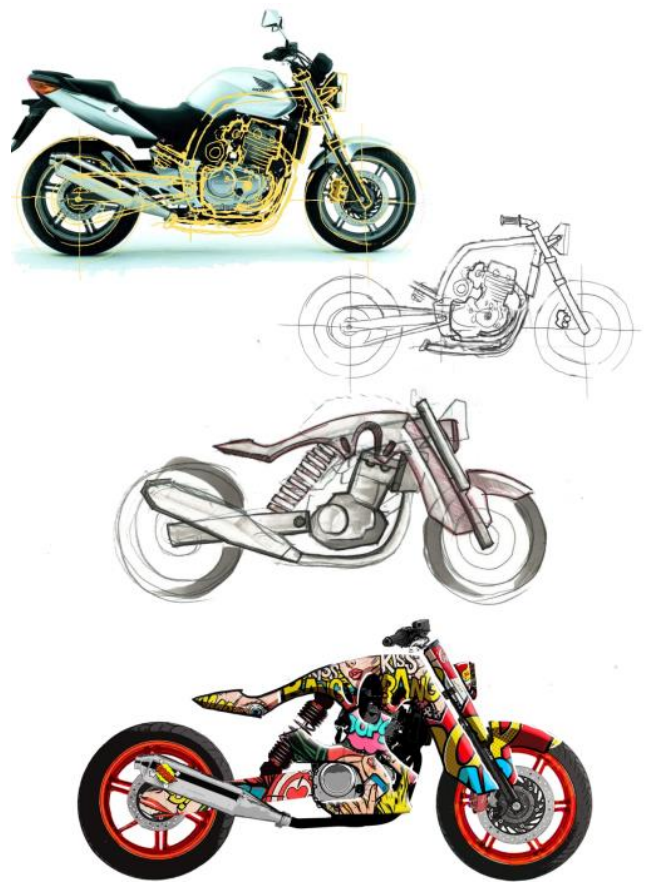

Fig. 9. Pop Art Sanat Akımı ile Tasarlanmış Motosiklet olarak incelenmesi yapılan araştırmalar ve alan uzmanlarının yönlendirmesi sonucunda kararlaştırılmıştır (Ersoy 2013, 339-370).

Araştırmaya en uygun veri toplama aracının anket olduğu belirlenmiştir. Alan uzmanlarına danışılarak alınan öneriler ve yönlendirmeler bağlamında anket soruları ve anketin genel tasarımı oluşturulmuştur. Araştırmanın anketi, veri toplama yollarının uygunluğu açısından alan uzmanına danışılıp, onay alındıktan sonra uygulanmıştır.

Süreç, tasarım öncesi literatür araştırmaları yapılarak başlamıştır. Ankette kullanılan soru kalpları önceden geliştirilmiş ölçekler baz alınarak araştırmacı tarafından uyarlanmıştır (Gümüş, 2017, 24-32). Anket beş puanlık Likert Ölçeği kullanılarak hazırlanmıştır. Anketlerin oluşturulma aşamasında bu konuda uzman bir danışmana danışılmış ve süreç boyunca desteğinden faydalanılmıştır.

Tablo 1. Aritmetik Ortalama ve Standart Sapma eğrisi

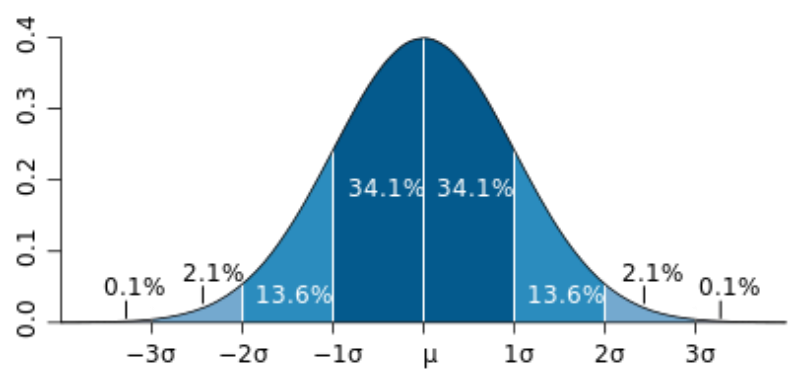

\section{Evren ve Örneklem}

Anketin uygulanma alanı olarak güzel sanatlar fakültesi öğrencileri, tasarımcılar, aktif olarak motosiklet kullanan kişiler belirlenmiştir. Kişilere ulaşmak için motosiklet kulüplerinin sosyal medya hesapları ve Akdeniz Üniversitesi'nin yüksek lisans öğrencileri grupları kullanılmıştır. 
Temel olarak çalışma grubu ikiye ayrılmış ve anket buna göre geliştirilmiştir.

\section{Anketin Analizi}

Anket sonuçlandırıldığında alınan verileriler SPSS programı ile analiz edilmiştir. Varyans analizi ve standart sapmaları alınarak yüzdeleri karşılaştırılan verilerin, oranları incelenmiş ve iki araştırma grubunun farkları ürünün genel ortalaması açısından yorumlanmıştır.

\section{Bulgular ve Tartışma}

Ortaya çıkan tasarımlarda seçilen sanat akımları ile motosiklet tasarımları arasındaki ilişkinin kullanıcılar tarafından tespit edilebilmesi bağlamında elde edilen sonuçlar oldukça tutarlıdır. Pop art, Barok ve Konstrüktivizm sanat akımları ile tasarlanmış motosikletler için bu başlık bağlamında üç soru sorulmuştur; ilk soru sanat akımı ile tasarlanmış ürün görseline uygun olacak şekilde, alt kısmında verilen beş farklı sanat akımı görselinden birinin seçilmesidir. Ayrıca ilk soruya bağlı olarak, seçmiş oldukları sanat akımını neden seçtiklerine dair acık uçlu bir soru eklenmiștir. Diğer soru ise akım bağlamında tasarlanmıș olan motosiklet ve bağlı olduğu akımın belirlenmiş olan bir görsel temsilcisi ile içerik anlamında benzerliklerinin derecelendirildiği bir sorudur.

Tüm akımlar için alınan geri bildirimler tasarımların ve sanat akımlarının birbiri ile görsel, işlevsel ve duygusal olarak ilişkili olduğu yönündedir. İlk soru için verilen toplam 162 cevaptan sadece üçü yanlış akımı seçmiştir ve açık uçlu cevapların genel ortalaması -beğeni gözetmeksizin- sanat akımları ile tasarımların ilişkili olduğuna dairdir. Üçüncü soruda her bir sanat akımı için elde edilen en düşük ortalama değer 5 üstünden 4,31'dir. Bu sonuçlar doğrultusunda hem tasarımcıların hem de motosiklet kullanıcılarının, motosikletlerin bağlı olarak tasarlandığı sanat akımlarını ayırt edebildiğini söyleyebiliriz.

Tablo 2. Likert Ölçeğine göre Stil görseli ve tasarım karşılaştırma sonuçlarının oranları .

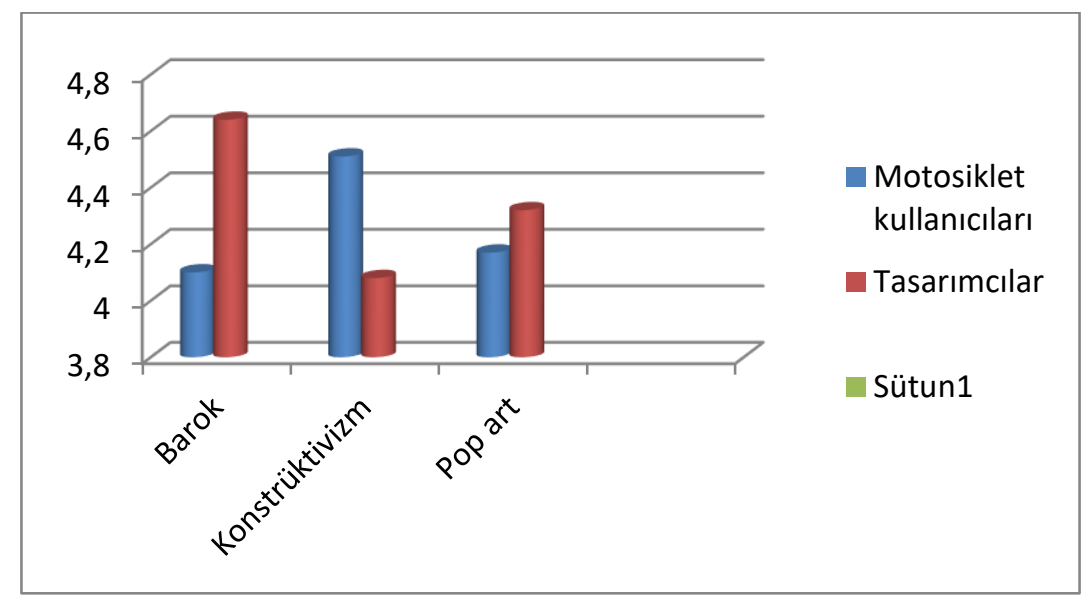

Ayrıca açık uçlu sorulardan elde edilen veriler doğrultusunda motosikletlere uygulanan sanat akımlarının görsel değerlerinin tasarıma artı bir değer katıp gözlenmektedir. Her sanat akımının özgün değeri motosiklet tasarımının görsel ve işlevsel tasarımına etki etmekte ve de kendi özgün içerikleri açısında bir değer katmaktadır. Örneğin Konstrüktivizm akımı tasarlanan motosikletin genel konstrüksiyonunu yani şasisini belirlemiş ve daha çıplak bir görüntü için grenaj kullanılmaması konusunda kararında etkili olmuştur. Bu yapı motosikletin genel görünümünü tamamen değiştirmiş ve kendine has bir görünüm katmıştır. Bu diğer tasarımlar içinde geçerli olan bir unsurdur. 
Tablo 3. Likert Ölçeğine göre Ortaya çıkan tasarımların özgünlüğüne veriler oranlar

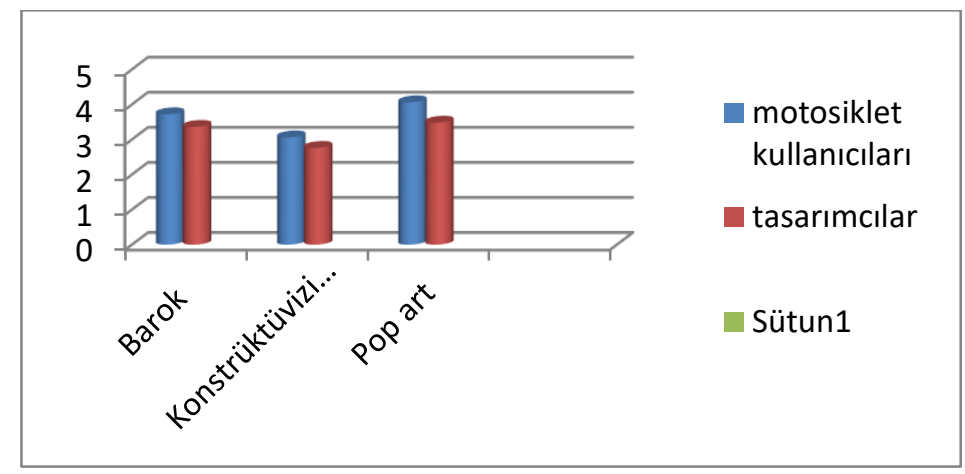

Anketlerden elde edilen sonuçlar şunu göstermektedir: Tüm motosikletlerde kullanılan temel düzenek aynı olmasına karşın Barok sanat akımı ile tasarlanmış örnek "klasik" diye nitelendirilip birtakım katılımcılar için beğeniden uzak olurken, bu katılımcılar Pop art ya da Konstrüktivizm akımını beğenmiş oluyorlar. $\mathrm{Bu}$ anlamda sanat akımlarının uygulandıkları ürüne, ürünün işlevsel özellikleri ve seçilen akımın estetik özelliklerinin sentezinden ortaya çıkan kendine özgü bir görsel değer kattıklarını söyleyebiliriz.

Çalışmanın irdelediği başlıklardan biri de tercih edilebilirliktir. Anket hazırlanırken bu başlık için özel olarak bir bölüm ayrılmış ve sonuçları incelenmiştir. Alınan cevaplar kapsamında Barok sanat akımı ile tasarlanan motosiklet örneği üzerinden "tercih" için verilen ortalama değer 5 üzerinden 2,68 iken Konstrüktivizm akımı ile tasarlanan motosiklet için verilen ortalama değer 4.24'tür. Bu sonuç ankete katılan kişilerin yaş ortalaması göz önüne alınarak ve yapılan yorumlar düşünüldüğünde, bu anket grubunun daha seri, modern ve dinamik görünen bir motosiklet ile daha çok ilgilendiğini söylemek mümkündür.

Yaptığımız açıklamalar ve anket doğrultusunda ortaya çıkan sonuçlar gözetilerek ortaya çıkan tasarım ürünlerinin özgünlüğü değerlendirildiğinde anket sonuçlarınca ters madde olan "Bu alış1lmış bir tasarımdır" maddesine Pop art için 5 üzerinden 1,62, Barok için 1,44, Konstrüktivizm için 3,03 değer verilmiştir. Bir diğer soru olan "Bu motosiklet tamamen yeni bir tasarımdır" maddesine ise Pop art için 5 üzerinden 4,06, Barok için 3,72, Konstrüktivizm için 3,60 değer vermişlerdir. Bu sonuçlar göz önüne alındığında genel anlamda tasarımların özgün olduklarını söylemek mümkündür.

Bir diğer başlık ise "Renk tercihi ve akımlar bağlamında anlaşılması"'dır. Genel ortalamada 162 cevap arasından 74'ü siyah, 34'ü mavi, 27'si sarı, 14'ü beyaz ve 14'ü kırmızıdır. Konstrüktivizm sanat akımı için en çok tercih edileceği söylenen renk maviyken, diğer sanat akımları ile tasarlanmış motorlarda seçilen renk siyah olmuştur

Tablo 4. Renk tercih ve oranları

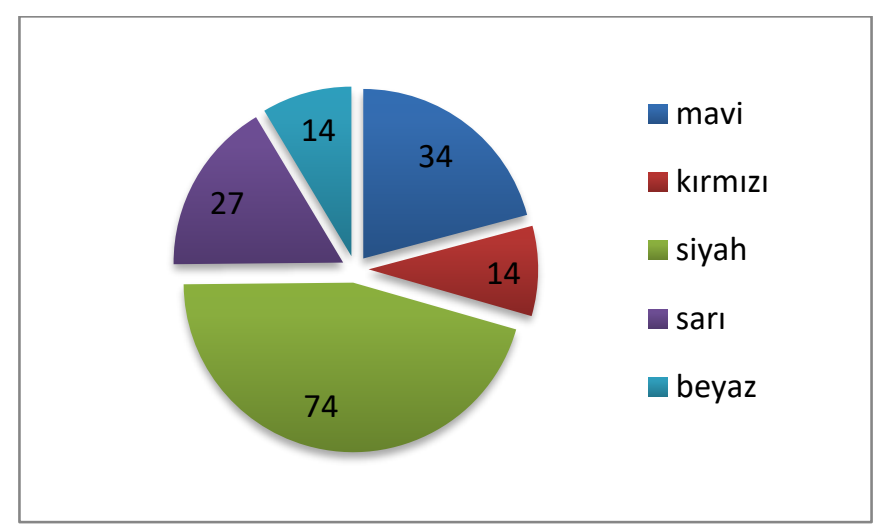




\section{Sonuçlar}

Çalışmanın kapsamı olarak; ritim, denge, oran-orantı (ölçek), vurgu, zıtlık, bütünlük, hiyerarşi gibi tasarım ilkeleri ve seçilen sanat akımlarının özel biçimleri belirlenmiş ve incelenmiştir. İncelemeler sonucunda fikir yürütülerek eskizler oluşturulmuş ve çıkan sonuçlar bağlamında tasarımlar tamamlanmıştır. Konu kapsamında belirlenen "CBF 500" model motosikletin egzoz, benzin deposu, jantlar gibi birçok parçası üzerinde belirlenen stiller bağlamında uygulamalar yapılmıştır. Siyah, sarı, kırmızı, mavi ve beyaz olmak üzere beş farklı renk, üç farklı sanat akımı özellikleri motosiklete uygulanmıştır. Ortaya çıkan tasarımlar anket yardımı ile değerlendirilmiş ve sonuçlar analiz edilmiştir.

Araştırma ve uygulama süreci boyunca ortaya çıkan sonuç sanat akımlarının ürün tasarlama sürecinde kullanılabileceği yönündedir. Anketlerden elde ettiğimiz sonuçlar göz önüne alınarak ürünler tasarlanırken temel tasarım ilkelerinin bir akımın özellikleri ile ilişkilendirildiklerinde, bunun tasarımın belirgin biçimde dönüşmesini sağladığı söylenebilir. Ve elde edilen sonuçlara göre birçok endüstriyel tasarım ürününde sanat akımları kullanılabilir, uygulandıktan sonra etkileri açık şekilde görülebilir, bu yöntem ürünlere yön verebilir ve kimlik kazandırabilir.

Sonuç olarak; endüstriyel tasarımda ürün tasarım sürecinde sanat ve stil akımları kullanılabilirliği ortaya koyulmuştur. Yapılan anketler sonucunda sanat akımı ve stil özelliklerinin, ürün tasarımında görsel olarak belirleyici olabileceği anlaşılmıştır. Yani bir ürün belirlenen sanat akımının temel özellikleri dikkate alınarak tasarlandığında bu akımların ürünler üzerindeki etkisi sanatsal olarak okunabilmekte ve bilimsel olarak tespit edilebilmektedir. Endüstriyel bir ürünün stil bağlamında tasarlandığında tamamen yeni bir kimlik ve tanınırlık kazanabileceği belirlenmiştir.

\section{KAYNAKÇA}

Antmen A. (2016). 20. Yüzyıl Batı Sanatında Akımlar. İstanbul 2016.

Ersoy E. (2013). Bilimsel Araştırma Yöntemleri. (ed.). Ankara 2013.

Gümüş, B. (2017). Design Effects on Consumer Choices: A Study on Technological Products. Yayımlanmamış Doktora Tezi. Bilgi Üniversitesi Sosyal Bilimler Enstitüsü, İstanbul 2017.

Hasol D. (2011). Mimarlık Sözlüğ̈̈. İstanbul 2011.

Hesskett J. (2013). Tasarım. Çev. E. Uzun. Ankara 2013.

Little S. (2006). İzmler: Sanatı Anlamak. İstanbul 2006.

Lynton N. (2015). Modern Sanatın Öyküsü. Çev. C. Çapan \& S. Öziş. İstanbul 2015.

Resim 32 : ipfs.io/ipfs/QmT5NvUtoM5nWFfrQdVrFtvGfKFmG7AHE8P34isapyhCxX/wiki/

Standart_sapma.html 